University of Nebraska - Lincoln

DigitalCommons@University of Nebraska - Lincoln

Faculty Publications, Classics and Religious

Studies Department

1998

\title{
William Ockham and Trope Nominalism
}

Stephen E. Lahey

University of Nebraska-Lincoln, slahey3@unl.edu

Follow this and additional works at: https://digitalcommons.unl.edu/classicsfacpub

Part of the Classics Commons

Lahey, Stephen E., "William Ockham and Trope Nominalism" (1998). Faculty Publications, Classics and Religious Studies Department. 85.

https://digitalcommons.unl.edu/classicsfacpub/85

This Article is brought to you for free and open access by the Classics and Religious Studies at DigitalCommons@University of Nebraska - Lincoln. It has been accepted for inclusion in Faculty Publications, Classics and Religious Studies Department by an authorized administrator of DigitalCommons@University of Nebraska - Lincoln. 


\section{William Ockham and Trope Nominalism}

Can we take a medieval metaphysician out of his scholastic robes and force him into a metaphysical apparatus as seemingly foreign to him as a tuxedo might be? I believe that the terminological and conceptual differences that appear to prevent this can be overcome in many cases, and that one case most amenable to this project is the medieval problem of universals. After all, the problem for the medieval is, at base, the same as it is for contemporary philosophers, as for Plato: How do we account, ontologically, for many tokens of the same type? If one object has the property $x$ and another, distinct object has the "same" property $x$, how to explain the apparent "sameness" of the property $x$ ? Is $x$ one property or two? I will argue that William Ockham's ontology, when considered in light of some contemporary philosophical thought, is remarkably fresh and vital, able seriously to be considered as a tenable position, so long as we are clear about what Ockham is saying. This clarity is no easy task, since so much of what Ockham said is rooted in an Aristotelian metaphysics most philosophers have, rightly or wrongly, abandoned. Our discussion will be an ontologically basic one; we will get clear on what Ockham believes there is, and how he believes there can be many tokens of the same type. A more detailed consideration of his logic of terms is precluded by the elementary nature of the discussion.

The discussion will be divided into two sections. First, I believe it will be helpful to set forth two positions familiar to the contemporary philosopher. D.M. Armstrong has catalogued nominalism as it is understood today in Nominalism and Realism ${ }^{2}$, and in his more recent Universals: An Opinionated Introduction ${ }^{3}$, and I will use these as our anchor to contemporary thought. Concept Nominalism is a species of nominalism that can easily be mistaken for the

'I would like to thank Ruth Garrett Millikan, A. S. McGrade, and Andrew Beedle for their comments on earlier versions of this paper.

${ }^{2}$ D. M. Armstrong, Nominalism and Realism: Universals and Scientific Realism Vol. 1 (Cambridge: Cambridge Univ. Press, 1978).

${ }^{3}$ D. M. Armstrong, Universals: An Opinionated Introduction (Boulder CO: Westriew Press, 1989). 
Ockhamist position, given the importance of concepts in his metaphysics, and so I will quickly outline the bare bones of this position, sufficient to show later on that it is not Ockham's. I will then discuss Armstrong's characterization of Trope Nominalism, a position he portrays as relatively innovative in his 1989 work. I think that Ockham's ontological program is something very like this Trope Nominalism, and in the second half of the discussion, I will argue this. That Ockham's position is innovative, not avowedly realist, yet not radically nominalist in the contemporary sense, is not news. Marilyn Adams recognizes this. "Since Ockham identifies Universals primarily with naturally significant names or concepts, it is perhaps less misleading to say that he was a conceptualist rather than a nominalist about Universals." ${ }^{4}$ But the tendency to identify "conceptualism" with Concept Nominalism, and hence with what will prove to be an untenable position, is dangerously tempting, and so first we must look at what is involved in Concept Nominalism.

\section{I \\ CONCEPT AND TROPE NOMINALISM}

All nominalists agree that the only things there are, are particular objects. Extramental Universals are for the realists. The nominalist question is, "What is it that allows us to use universal terms to describe these objects?" For the Concept Nominalist, it is only that a particular object fall under a concept, while for a Tropist, as we will see later, more is involved.

" $\mathrm{X}$ has the property $\mathrm{F}$ if $\mathrm{x}$ falls under the concept of $\mathrm{F}$ " means that (what makes) a certain object's (possession of the property) "being white" (simply is determined by the fact that) the concept 'white' applies to the object. But if the concept 'white' did not exist, would the object not still be white? If so, the object's whiteness is constituted by something more than the object's relation to the concept 'white', and we are dealing with something more than Concept Nominalism. If there is something about the particular that explains why the concept 'white' is applicable to it,

"Marilyn McCord Adams, William Ockbam (Notre Dame IN: University of Notre D2me Press, 1987) 73. 
aside from or more than the brute fact that it does not apply, there is ontologically more than the Concept Nominalist will admit to.

If the Concept Nominalist tries to slide around this by explaining that particulars falling under the same concept do so because of the resemblance which these particulars have to each other; if, like Locke, they refer to the "similitudes of things," then the resemblance must be taken as a real relation, and something more ontologically rich than Concept Nominalism is involved, namely, Resemblance Nominalism. If we are determined to proceed along a Concept Nominalist line, keeping our ontology as bare as it seems we must, Armstrong suggests, we will quickly find the position to be untenable.

Take the class of white things. For the Concept Nominalist, this class may have its unity because each of its members has the "falling under" relation to the same concept, 'white'. That is, each of the members of the class has a sameness of type; each white thing has the same sort of relation to the concept 'white'. So the Concept Nominalist seems to want to have types as being things in the world, which is also inadmissible, for all there are that make objects white are concepts, not types. To claim that the type 'white' is the class, or type, of its tokens is to suggest Class Nominalism, not Concept Nominalism.

And what of "falling-under"? If all objects are related to concepts by the common relation-type "falling-under", we have a relation-type being given more ontological weight than a Concept Nominalist is able to admit, since there can be no relations save as constituted by concepts. This, Armstrong believes, leads to an object regress, from which no escape seems possible. A relation regress is also inescapable.

Again, falling-under is a type of relation. Pairs of particulars and concepts can only be considered tokens of this type if they fall under the concept falling-under. But this new falling-under again requires analysis. ${ }^{6}$

Further, the world's causal order seems to depend on the properties of the particular objects therein, and is mind-independent for all

\footnotetext{
${ }^{5}$ See John Locke, An Essay Concerning Human Understanding, III, Chpt. VI, xxrvi.

${ }^{6}$ D.M. Armstrong, Nominalism and Realism: Universals and Scientific Realism, 27.
} 
save the Humean or the Idealist. "But, inconsistently, the Concept Nominalist holds that the properties of things are determined by a certain relation which things in the world have to objects in minds." This means that, for the Concept Nominalist, causality is ultimately mind-dependent, thus forcing him either to admit to Humean skepticism or defeat.

Armstrong characterizes Concept Nominalism as a subjectivist solution to the problem of universals. Universality is located entirely in the human mind, and man is effectively the measure of all things. Locke, Berkeley, and Hume appear to have leaned towards Concept Nominalism, in that they felt that their analysis of concepts or "ideas" explained how it is and what it is for a particular object to have a property or relation. As mentioned, Locke was prone to slipping a "natural similitude of things" in along with the particular objects that there are in the world, which would, strictly speaking, make him more a Resemblance Nominalist. Armstrong describes the Concept Nominalist position as untenable, if not for its problems with causality, then certainly for its inescapable object and relation regresses.

The Tropist position is much more plausible. Tropes are also called "cases" or "concrete properties"; they are properties and relations as particulars, or "particularized Universals." To be a Trope Realist, one would need to hold a set of Universals in which the particularized Universals, or Tropes, participate, but this would seem an unnecessary position-why postulate Tropes if espousing realism? That is, why add particularized universals to an ontology already rich enough to admit to non-particularized universals? Trope Nominalism is a much more interesting approach, for it allows us to recognize not only particular objects, but also particular properties and relations as ontologically available to the metaphysician, while not committing ourselves to full-blown realism.

Armstrong suggests that we might view Tropes, particular properties and relations, as organized into objects in either of two possible ways. We might follow Russell's lead and explain objects as bundles of properties united by compresence, although we would eschew Russell's bundle-of-universals account in favor of bundlesof-Tropes. Armstrong prefers another view, one more suited to the

${ }^{7}$ Op.cit. 
medieval approach. He describes a substance-attribute model of explaining how Tropes are combined to make particular substances; "...particulars have properties and stand in relations to other particulars." The particular objects are the substances that have particular properties and (thereby) particular relations to other particular objects. Is the underlying substrate in which all Tropes inhere inimical to this view? There need not be some invisible metaphysical core to every object in which properties mysteriously inhere, although Armstrong seems to admit that this is a possibility in his talk of "thin particulars" as the basis for substance-attribute realism, and while we are dealing with Trope Nominalism I do not think his argument has changed overmuch, but then $I$ also doubt that we are necessarily bound to admit the need for these "thin particulars." What makes these particular properties and relation parts of this particular object are what Armstrong calls states of affairs, or facts.

Let us look at what states of affairs are from a Trope Nominalist position. We have a particular property $\mathrm{F}$, a particular object $\mathrm{x}$ in which $\mathrm{F}$ could inhere, and we have an inherence relation, allowing the possible inherence of $\mathrm{F}$ in $\mathrm{x}$. But this does not give us $\mathrm{Fx}$; what is needed for $F x$ is that $F x$ is the case, that $F$ inheres in $x$ as a fact, a state of affairs, $\sim \mathrm{Fx}$, because it would be a fact that $F$ does not inhere in $\mathrm{x}$. Armstrong explains that these states of affairs rest on a "truth-maker principle." "According to this principle, for every contingent truth at least (and perhaps for all truths contingent or necessary,) there must be something in the world that makes it true." In our case this something would be the fact that Fx or that $\sim F x$. So, while particular object $x$ and particular property $F$ could exist without $x$ being $F$ (particular property $F$ would have to be in some other particular object, of course), $x+F$ does not necessitate $x$ 's being $F$; what makes it the case is that Fx is a fact.

States of affairs are not something ontologically more than their constituents. "States of affairs flow necessarily from, supervene on, the bare existence of their constituents." 10 But is not spatiotemporality an important factor to consider in determining

\footnotetext{
${ }^{8}$ D. M. Armstrong, Universals: An Opinionated Introduction, 114.

${ }^{9}$ Tbid, 88-89.

10Tbid, 118 .
} 
facts? Particular property F might very well be "being in Location $\mathrm{L}$ at Time $\mathrm{T}$," in which case, all that would be needed for $\mathrm{Fx}$ is that the state of affairs "that $\mathrm{x}$ is in $\mathrm{L}$ at $\mathrm{T}$," obtain. Relations also present no problem from this standpoint. Let us examine $x$ 's particular relation $x R y$. Assume that for $x R y$ to be the case, $F x$ and $\mathrm{Gy}$, in which $\mathrm{F}$ and $\mathrm{G}$ are Tropes, must also be the case. If state of

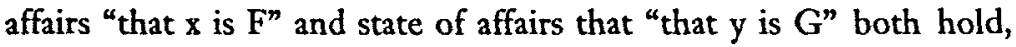
all other things being equal, it is certainly possible to recognize the conjunct state of affairs, " $F x$ and Gy" as obtaining. So we automatically have met the criteria xRy from the state of affairs being the case. This particular relation as formulated is about $\mathrm{x}$ and its relatedness to $y$, and is something other than a relatedness that $y$ might have to $\mathrm{x}$, unless the relation is a reflexive one, which has not been a part of the description. Thus we can admit particular relations, or relation-Tropes into the picture. ${ }^{11}$ Because of this, we area able to escape the regresses that bedevil Concept Nominalism.

States of affairs have accounted for most particular relations, but inherence needs more explanation, since it was taken as given in observing how states of affairs operate. Inherence seems to be a relation-type, and ought to be a third party in any state of affairs Fx. But let us look at inherence as a higher-order relation that $F$ must itself have; if Tropes can themselves have Tropes, it would appear that inherence will not present any major problem, given states of affairs.

If we have $F$ as a possible particular property and $x$ as a possible particular object, if state of affairs Fx obtains, it would seem that F would itself have to have the relation of inherence to $x$. Armstrong seems not to have any difficulties with this, so long as we are not arguing from the way language works to higher-order properties, "a very a priori way of proceeding. ${ }^{12} \mathrm{He}$ suggests that a substanceattribute model of the relation of a first-order Trope to its own particular property is plausible-if the state of affairs is such that $F$ has the inherence-relation when $\mathrm{Fx}$ obtains, all that is needed to explain how this is so is an explanation of how Fx is so, which has already been given. No regress need arise, because states of affairs have put the cap on any possibility of one. But in his discussion of

\footnotetext{
"See Ibid, 126.

${ }^{12}$ Op. cit.
} 
universals, Armstrong admits that instantiation is a primitive, and cannot be explained; the same may be necessary for our description of inherence, because inherence works in Trope Nominalism in very much the same way instantiation works for a realist position.

It seems easy to envision a relation regress for inherence if Tropes themselves can have higher-order Tropes, but Armstrong insists that a state of affairs is something that is irrefutable, and so staves off the specter of regress with the finality of fact. It appears best to admit inherence to be a primitive, though, in case epistemological questions arise concerning whether knowledge about states of affairs is certain in every case.

This is a sufficient description of the essentials of the Trope Nominalism position on which to map Ockham's ontology. We have a nominalist theory that admits of particular properties and relations, that puts a heavy emphasis on a reliable recognition of states of affairs, on the way things are in the world, and we have inherence as a real, albeit primitive relation, admissible so long as not merely necessitated by (artificed) linguistic structure.

II

INTRODUCING TROPES TO OCKHAM

For Ockahm, all that there are in the world are particular objects and particular qualities (relations will be discussed below.) There are no Universal things, only singulars.

Everything outside the soul is really singular and numerically one, for anything outside the soul is either simple or composite. If it is simple, it does not include many things...If it is composite, one will finally have to arrive at a certain number of parts. Consequently each of these parts will be numerically one. ${ }^{13}$

${ }^{13}$ William Ockahm, Ordinatio d.2, q.6, Paul V. Spade transl., draft, 1986. [All references to Ockaham's Latin works are to the editions of Guillelmi de Ockbam, Opera Tboelogica $[O T b]$ and Opera Pbilosopbica at Tbeologica [OPTb], G. Gal, O.F.M. at al. eds. (St. Bonaventure NY: Franciscan Institute, 1966-1988) OTb I, 196.13-21 “...omnis res extra animam est realiter singularis et una numero, quia omnis res extra animam vel est simplex vel composita....Si sit composits, tandem oportet devinere ad certum numerum partium, et per consequens quaeliber illarum partium erit una numero...." 
We cannot claim that there are particular properties, as Armstrong does, because we are dealing with different terminology, based on the Aristotelian categories. "A property, then, does not inhere in the subject whose property it is said to be." 14 Properties are intentions that connote something extrinsic to what is designated by the subject; "it can be something which is by nature predicable, or it can be a proposition existing or capable of existing in the mind. ${ }^{15}$ Quite simply, a property is species of Universal, or concept (the two are synonymous), by which we understand how things are in the world. And since there are particular qualities, a property can connote in a concept what is really distinct from a particular object (or substance) that is the subject of a concept.

We are bound by a different ontological terminology when dealing with an Aristotelian metaphysics, but this should not be so daunting. What Ockham describes as particular substances and particular qualities roughly correspond to particular objects and particular properties. But particular qualities must be further explained; are there not eight other categories to be accounted for? As Ockham sees it, all the other categories, quantity, relation, action, and the rest, fall ontologically under the category quality. The distinctions implicit in the categories are worth preserving for Ockham, but the distinctions of the "other eight", aside from substance and quality, are not rooted in the kinds of things, but in the kinds of names of things. "...I claim that substance, quality, and quantity are distinct categories, although 'quantity' does not signify any absolute things that are distinct from substance and quality." 16

\footnotetext{
${ }^{14}$ Surrma Logicae I, Chpt. 24, in Ockbam's Theory of Terms. Part I of the Summa Logicae, Michael J. Loux, transl. (Notre Dame, IN: Univ. of Notre Dame Press, 1974) 101; OPTb $1,79.40$, "Non solum autem tenendum est quod proprium non semper est inhaerens subiecto cuius dicitur proprium..."

${ }^{15}$ Ibid, 102; OPTb I, 80.78-81.80 "Non tamen oportet quod semper illud extrinsecum sit aligau res extra animam, exsistens realiter in rerum natura, sed forte aliquando sufficit quod sit aliquid possibile in rerum natura, vel forte digno propositio exsistens vel potens in mente exsistere."

${ }^{16}$ Quodlibet $I V, q .27$ in William of Ockham, Quodlibetal Questions, Vol. 1, Alfred J. Freddoso and Francis E. Kelley (Yale Library of Medieval Philosophy: Yale Univ. Press, 1991) 360. Otb $[X, 436.65-68$ “...dico quod substantia, qualitas, quantitas sunt distincta praedicamenta, quamvis non significent rem absolutam distinctam a substantia, et qualizate, quia sunt distincti conceptus et voces easdem res diversimode significantes."
} 
But it is one thing to say that all that there are are particular substances and their particular qualities; given the categories, we must explain why the "other eight" fall ontologically under quality. We can kill two birds with one stone if we address relation. It is one of the "other eight", and so ontologically falls under quality. Thus it is something that is, in a sense, real, and so describing it will facilitate our comparison with contemporary Tropist thought.

In Ordinatio I, dist. 30, Ockham explains how relation is subordinate to substance and qualities in the form of a response to those of his contemporaries holding a three term view of relation. The three term view implies that, for relation $x \mathrm{xy}$, there are three really distinct things involved: $x, y$, and relation $R$. Ockham argues that, since every thing distinct from other things in reality is understandable without the other things being understood, a three term view is impossible. For if relation $R$ were a really distinct thing from $x$ and $y, R$ would be understandable without considering $\mathrm{x}$ and $\mathrm{y}$. "But it is impossible for something which is a relation to be understood without any other thing." $" 17$

Take the relation of similarity that is said of Socrates and Plato with respect to their whiteness. One could not speak of this similarity without an understanding of Plato's whiteness and Socrates' whiteness. How then can we understand the proposition, "Socrates is similar to Plato with respect to whiteness"? It sounds as if the relation of similarity is being predicated of Socrates as an ontologically real category, as something really distinct from Socrates that Socrates has. But this is not the way things are. If this proposition is to be true, Socrates must have the particular quality whiteness, and Plato must also have particular whiteness. If the conjunct quality predication obtains, Socrates is similarity-related to Plato automatically, by virtue of the fact that both are white. "Whence he who could understand Socrates and Plato and their whitenesses, with nothing else understood, would say at once that Socrates is similar to Plato. ${ }^{n 18} \mathrm{We}$ can see from this that the

${ }^{17}$ Ordinatio I, dist. 30, q. 1, in Arthur Hyman \& James Walsh, Pbilosopby in the Middle Ages, 2d ed. (Indianapolis, IN: Hackett Press, 1986) 680. Otb IV, 287.17 "...sed impossibile est aliquam rem, quae sit relatio, intelligi sime omni alia re...."

${ }^{18} \mathrm{Ibid}, 682$; OTb $I V, 310.6-8$ "Unde qui poset intelligere Sortem et Platonem et albedines eorum, nihil aliud intelligendo, statim diceret Sortem esse similem Platoni." 
relation is not something ontologically added to Socrates being white and Plato being white, yet it makes sense to say that this relation is real, in the sense that it is not something constituted by the human understanding.

But it should be imagined that the intellect contributes no more to the fact that Socrates is similar than the fact that Socrates is white. Indeed, from this itself, that Socrates is white, and that Plato is white, Socrates is similar to Plato with everything else imaginable aside. [And thus Socrates is similar to Plato solely by absolutes, with all else either in things or in the intellect aside.] And so, nothing exists in reality outside of absolutes. ${ }^{19}$

For Ockham's purposes, a relation is not something real in the same sense that a particular substance or a particular quality is real, because the relation is not really distinct from a certain state of affairs obtaining with regards to a given substance and quality. That is, relations are not three term affairs. But for Armstrong's Trope Nominalist purposes, Ockham's relations are real enough, in that it is not something constituted by the mind, as would be the case for a Concept Nominalist. I hope to have shown in this example that Ockham's conception of relation is not unlike that of the Tropist, and also how the "other eight categories" are able to be incorporated under the ontologically real category of quality.

Next we should address the relation of inherence. Is this relation a quality of a quality in the same way that it was characterized as a higher-order Trope? Armstrong suggests that Tropes might have higher-order Tropes on the substance-attribute model, with states of affairs frustrating regress, but this option does not appear to be open to Ockham. Relations are real enough in the Tropist sense, but recall that for Ockham they have their basis in kinds of names of things, not in things, so perhaps the problem of whether particular qualities in themselves have relations, like the particular quality of white having the particular inhering-in relation

${ }^{19}$ Tbid, 684; OTb $N, 316.10-16$ "Sed sic est imaginandum quod intellectus nihil plus facit ad hoc quod Sortes sit similis quam ad hoc quod Sortes sit albus. Immo ex hoc ipso quod Sortes est albus et Plato est albus, Sortes est similis Platoni, omni alio imaginabili circumscripto. [Et ita Sortes est similis Platoni propter sola absoluta, omni alio velinre vel in intellectu circumscripto.] Et ita in re nihil est praeter absoluta." (Bracketed sentence not included in Walsh translation.) 
to Socrates, becomes a question of how names, or terms, are ordered. ${ }^{20}$

But this will not do as an adequate explanation; the accidents of the bread exist in exactly the same place as the body of Christ without inhering in it as accidents in substance. And if God can do that, surely God could bring it about that the accidents of any substance, while remaining substantial, first do, then do not inhere in that substance? Inherence seems to be something clearly distinct from particular qualities on doctrinal grounds. Have we a relation here not based on the names of things, but rather on things? Marilyn Adams suggests that Ockham can make an exception of inherence in this case, since "... inherence-the relation between any putative accident-thing and its substance-is not included under any of the species of relation or other accidents recognized by Aristotle in the Categories. ${ }^{21}$ I would suggest declaring the relation of inherence's real distinguishability to be a primitive, without which the ontology just would not make sense, and leaving it at that.

We ought to note here what we are talking about when we mention a particular substance. What makes this substance a particular substance is not some metaphysical constituent of the particular substance; Ockham, if an essentialist at all, is much less of one than his moderate realist contemporaries. “...[I]n creatures there can never be any distinction outside the mind unless there are distinct things; if, therefore, there is any distinction between the nature and the difference, it is necessary that they really be distinct things." 22 The particular substance is particular because this form and this matter are taken as combined. Are matter and form particular qualities of substance? It would seem not; not in the way that this white or this roundness are particular qualities inhering in this particular substance. It is out of this matter and this form that these particular qualities arise.

The only thing in Socrates which can be constructed as substantial is this particular matter, this particular form, or the

\footnotetext{
${ }^{20}$ See Summa Logicat I, Chpt.44.

${ }^{21}$ Marilyn McCord Adams, William Ockbam, 276.

${ }^{22}$ Summa Logicae I, cap. 16, Loux, 83. OPTb $1,54.11-14$ "...in creaturis nunquam potest esse aliqua distinctio qualiscumque extra animam nisi ubi res distinctae sunt; si igitur inter istam naturam et istam differentiam sit qualiscumque distinctio, oportet quod sint res realiter distinctae."
} 
composite of the two. And therefore every essence and quiddity and whatever belongs to substance, if it is really outside the soul, is just matter, form, or the composite of the two. ${ }^{23}$

The point of this is to show that it seems difficult to think of substance as exactly the same sort of base for inherent qualities as Armstrong's "thin particular"; this complexity of how and in what particular qualities inhere further shows the utility of espousing the primitivity of the inherence relation.

Now that we have assembled the necessary ingredients, can we claim states of affairs for Ockham? I believe that here our argument for a Tropist position is strongest. It would seem a potentially dangerous area, since here Ockham's conceptualism is a critical factor, and we have been warned about the shaky a priori nature of an appeal to an artificed structure in laying out an ontology. But as we will see, Ockham's conceptualism is quite amenable to reliable states of affairs characterization.

In the Tropist position, simply having the ingredients for $\mathbf{F x}$ was not enough; what was needed was that $\mathrm{Fx}$ obtain as a state of affairs. How does Ockham characterize how Fx can obtain as a state of affairs? He is not bound, as are the Empiricists, to sense-data theorizing epistemologically; Ockham believes that an intuitive cognition of something in the world affords direct access to the way things are. "...I say that the intellect at first knows the singular intuitively. This is because the intellect knows intuitively what exists in reality, but nothing is such unless it is singular." ${ }^{24}$

Once this intuition is made, say an intuition of a white object, the intellect is able immediately to abstract from the intuitive cognition and form a "complex" along the lines of, "this body is white", and judge the truth of the complex. But, "...neither the formation of the complex nor the act of assenting to the complex is

\footnotetext{
${ }^{23} \mathrm{Ibid}, 84$, OPTb $1,57.79-83$ “...sed quiquid imaginible substantiale exsistens in Sorte vel est materia particularis vel forma particularis vel compositum ex his. Et ideo omnis essentia et quidditas et quidquid est substantiae, si sit realiter extra animam, vel est simplicter et absolute materia vel forma vel compositum ex his..."

${ }^{24}$ Reportatio II, q. 13, Hyman and Walsh, 677 [incorrectly listed as q. 15] OTb $V$, 284.14 "...dico quod intellectus primo intelligit singulare intuitive. Tum quia intellectus intelligit illud quod est in re intuitive; sed nihil est tale nisi singulare."
} 
intuitive cognition." 25 These are abstractive cognitions, where the propositions or complexes that comprise the concepts are constructed and judged, and they require intuitive cognitions for their formation. Ockham explains that it is possible to make evident judgements at this elementary level. "A non-complex knowledge of purely intelligible terms is sufficient for evident knowledge of a contingent truth." ${ }^{26}$ But complex propositional knowledge is required to get at the truth of things.

What does this amount to? The key to the matter lies in his reference to a "singular." Ockham explains that a singular is "...taken for a thing that is numerically one, and that is not a natural or voluntary or conventional sign that is common to many. ${ }^{27}$ This seems an effective definition for a fact, a state of affairs in the world. Let us now posit a simple state of affairs, Fx. The intellect intuitively cognizes $F x$ by recognizing ( $F, x$, inherence). At this stage, a contingent truth can be known: it could be the case that, given ( $F, x$, inherence), $F x$ obtains. When the intellect forms for itself, through a natural sign or concept, the proposition " $\mathrm{Fx}$ ", it can judge for itself by abstractive cognition that " $\mathrm{Fx}$ " is true, and thus that the singular, Fx, a state of affairs in the world, obtains.

Could God arrange for intuitive cognition of a singular that does not, in fact, obtain? This would allow for the intuitive cognition of non-existents, which might threaten our state of affairs model. Ockham recognizes that this is certainly a possibility.

If it (the intuitive cognition) is naturally caused, then it cannot be unless the object exists and is present in the required proximity.... But if it is supernatural, for instance, if God should cause in me the intuitive cognition of some object existing at Rome, immediately upon the cognition of it I can judge that that

${ }^{25}$ Op.cit. OthV, 293.2-4 "Unde sicut non omnis notitia incomlexa est generative habitus incomplexi, ita nec omnis notitia complexa est generativa habitus complexi."

${ }^{26}$ Ordinatio, prologus, q. 1, in William Ockham, Pbilosopbical Writings, Philotheus Boehner, O.F.M. ed. and transl., revised by Stephen Brown (Indianapolis, IN: Hackett Press, 1990) 21. OTb 1, 29.3-5. "...sola notitia incomplexa terminorum mere intelligibilium sufficit ad notitiam evidentem talis veritatis contingentis."

${ }^{27}$ Quodlibet $I, q .13$ in William of Ockbam, Quodlibetal Questions, Freddoso and

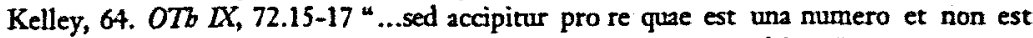
signum naturale vel voluntarium sive ad placitum commune multis...." 
which I intuit and see exists, just as well as if that cognition were had naturally. ${ }^{28}$

This does not threaten the model at all, for God will not deceive us through this supernatural cognition, but will only give us a greater-than-natural access to states of affairs.

But speaking of access to states of affairs, what is the ontological status of a concept? If it has a different sort of being than things in the world, might not the reliability of the direct access to states of affairs be questionable? Ockham initially gave concepts "objective existence", making them nothing more than thought-objects in the mind, "a kind of mental picture which as a thought-object has a being similar to that which the thing outside the mind has in its real existence. ${ }^{229}$ But Ockham saw that this objective being was really nothing, and so not a reliable way of describing how it is we come to recognize states of affairs. He then concluded that a concept is a mental act, the same as the act of knowing, which more easily allowed him to say that the concept is a reliable representation of how things are in the world, since it has the same sort of being as any other act of a substance. ${ }^{30}$ Ockham explained that these were states of minds capable of naturally signifying that for which they stand. While Armstrong does not tackle epistemological problems at this level in his explanation of Trope Nominalism, we would presume that he believes that we can have as certain a knowledge of states of affairs as Ockham believes that we can.

We have already said that these concepts representing things in the world do so in the form of propositions; have we thereby committed the argument from linguistic structure against which

\footnotetext{
${ }^{28}$ Reportatio II, q. 13 Hyman and Walsh, 672. OTb V, 258.11-23 "Nam si naturaliter causetur, tunc non potest esse nisi obiectum exsistat praesens in debita approximatione;...Si autem sit supernaturalis, puta si Deus causaret in me cognitionem intuitivam de aliquo obiecto exsistente Romae, statim habita cognitiione eius intuitiva possum iudicare quod illud quod intueor et video est, ita bene sicut si illa cognitio haberetur naturaliter."

${ }^{29}$ Ordinatio 1, dist. 2, 9. 8, in William Ockham, Pbilosopbical Writings, Boehner, 41, OTb $I, 271.14-272.2$ “...universale non est aliquid reale habens esse subiectivum, nec in anima nec extra animam, sed tantum habet esses obiectivum in anima, et est quoddan fictum habens esse tale in esse obiectivo, quale habet res extra in esse subiecto."

${ }^{30}$ See Expositio in librum Peribermenias Aristotelis Lib. I, cap. 6, in OPTb II, 351-356.
} 
Armstrong warned? Are we led to posit an ontology on the basis of how concepts form in our minds? Ockham recognizes that this charge can be made, and responds with a distinction between written and spoken words on the one hand and mental words on the other. Spoken and written words signify through convention, through artificed language. "Homo," "Man," and "Homme" refer to the same creature because they are words invented to do so. But mental words, or conceptual terms, do not. "The conceptual term is an intention or impression of the soul which signifies or cosignifies something naturally and is capable of being a part of a mental proposition and of suppositing in such a proposition for the thing signified." ${ }^{31}$

The mind's own intellectual acts are called states of mind. By their nature they stand for the actual things outside the mind, just as the spoken words stand for them by convention. ${ }^{32}$

If this is the case, Ockham will escape the subjectivity of the Concept Nominalist position, because concepts naturally represent states of affairs. The trouble with this is that it is hard to prove. In fact, it is the nature of this problem that caused Wittgenstein to turn away from his stated project in the Tractatus; not only is Ockham relying on our understanding of the world based on a mental language, but he is also claiming that this mental language develops to become the same "language" in all of us, and that it naturally signifies how things are in the world. Ockham's response to this horrified question of "how can this possibly be proven?" might well be a simple, "how can it be disproven?" After all, every other link in this chain seems sound. Although we have not examined Ockham's term logic and his explanation of the types of signification mental terms exhibit, most will agree that his account of this was thorough, and his ontology certainly seems tenable enough, insofar as it meets Armstrong's Tropist demands. If we recognize that, while natural signification seems impossible to

${ }^{31}$ Summa Logicae I, cap. 1, Loux, 49. OPTb I, 7.19-21 "Terminus conceptus est intentio seu passio animae aliquid naturaliter significans vel consignificans, nata esse pars propositionis mentalis, et pro eodem nata supponere."

${ }^{32}$ Expositio in Librum Peribermenias Aristotelis Lib. I, cap. 6 in William of Ockham Pbilosopbical Writings, Boehner, 44. OPTb I, 351 "Breviter igitur, ipsae intellectiones animae vocantur passiones animae, et supponunt ex natura sua pro ipsis rebus extra vel pro aliis rebus in anima, sicut voces supponunt pro rebus ex institutione...." 
prove, it's corresponding impossibility to be disproven allows us a safe bridge between states of affairs in the world and our understanding of them. Further, it is no more unpalatable then Armstrong's assumption that we can reliably know enough about states of affairs.

These are not persuasive enough arguments for philosophers accustomed to the rigors of analytic thought, but I think that if more convincing arguments are attempted in favor of natural signification, Ockham's ontology would be hard to dismiss in the contemporary discussion. I hope to have shown how Ockham's ontological position is largely in accord with Trope Nominalism as described by D. M. Armstrong. Armstrong does not address the problem of how mental terms signify; natural signification might be necessary in the Trope Nominalist position as well, if his confidence in the reliability of human thought and language, and hence of human science, to represent states of affairs in the world is as strong as I believe it to be. 